\title{
Role of cholecystokinin in pancreatic adaptation to massive enterectomy
}

\author{
P Watanapa, M Egan, P H Deprez, J Calam, C E Sarraf, M R Alison, R C N Williamson
}

\begin{abstract}
Since pancreatic adaptation to massive proximal small bowel resection (PSBR) may be modulated through cholecystokinin (CCK) secretion, we tested the effect of the CCK antagonist CR-1409 on this response. Male Wistar rats $(n=72)$ weighing $220-225 \mathrm{~g}$ were randomised to receive either PSBR or transection/resuture followed by saline or CR$1409(12 \mathrm{mg} / \mathrm{kg}$ daily subcutaneously). Rats were killed one, two, and three weeks postoperatively, at which time blood was obtained for CCK assay and the pancreas was assessed for proliferative activity by three parameters: nucleic acid and protein content, bromodeoxyuridine (BrdUrd) labelling index, and proliferating cell nuclear antigen (PCNA) expression. PSBR increased plasma CCK concentration by $83-102 \%$ at $1-3$ weeks, irrespective of CR-1409 administration. Total pancreatic DNA content per $100 \mathrm{~g}$ body weight increased by $34 \%$ at two weeks $(p<0.05)$ and by $82 \%$ at three weeks $(p<0.05)$, while RNA content increased by $60 \%$ and $178 \%(p<0.001)$ and protein content by $20 \%$ and $57 \%(p<0.05)$. PSBR increased the BrdUrd labelling index and the percentage of PCNA immunoreactive cells. CR-1409 completely abolished this proliferative response and also prevented the rise in nucleic acid and protein contents. Apart from growth stimulation, PSBR also enhanced pancreatic exocrine function, as shown by ultrastructural evidence of an appreciable decrease in zymogen granules; CR-1409 also inhibited this functional effect of hypercholecystokininaemia. The results confirm the tropic role of CCK after PSBR, and CR-1409 prevents this pancreatic adaptation.
\end{abstract}

The compensatory response to extensive proximal small bowel resection (PSBR) includes growth of the remaining small intestine (duodenum and ileum) and of the gastric parietal cells, causing acid hypersecretion. ' The pancreas shares in this adaptive response. Pancreatic hyperplasia can be detected as early as one week after $90 \% \mathrm{PSBR}^{2}$ and persists for at least six months. ${ }^{3}$ Fifty and $75 \%$ PSBR also produce early and appreciable increases in basal pancreatic secretion of water and bicarbonate, but unlike the structural adaptation, these functional changes are transient. ${ }^{4}$

Intestinal adaptation to PSBR is controlled by both luminal and humoral factors, ${ }^{1}$ but since the pancreas lies outside the alimentary tract, only systemic factors seem likely to mediate its adaptive response. There are several candidate gastrointestinal hormones for the role of 'pancreatotropin'. Although long term administration of pentagastrin can stimulate pancreatic growth and enterectomy causes hypergastrinaemia, ${ }^{56}$ studies in rats with antrectomy or vagotomy have excluded its involvement in the response to PSBR. ${ }^{78}$ Circulating levels of insulin, pancreatic glucagon, and neurotensin are unchanged after small bowel resection, whereas enteroglucagon is increased and concentrations correlate with indices of musocal mass and cell turnover in the pancreas. ${ }^{29}$ Cholecystokinin is also increased 12 days after PSBR, ${ }^{9}$ and persistent hypercholecystokininaemia can certainly cause pancreatic hyperplasia. ${ }^{10}$ The present study was designed to test whether massive $(90 \%)$ PSBR would remove sufficient enteroendocrine cells to prevent the hypercholecystokininaemia of lesser enterectomies and, if not, whether the CCK receptor antagonist CR-1409 would blunt the adaptive response of the pancreas. Daily administration of CR-1409 can inhibit CCK induced pancreatic growth after pancreatobiliary diversion."

Pancreatic mass can be assessed by measuring wet weight, nucleic acid contents, and protein contents. We have attempted to measure cell proliferation, which should precede any increase in organ mass, by adopting two immunohistological methods to the pancreas: proliferating exocrine cells were labelled either with 5-bromo2 '-deoxyuridine (BrdUrd) or with a monoclonal antibody (PC10) against proliferating cell nuclear antigen (PCNA).

\section{Methods}

\section{EXPERIMENTAL DESIGN}

Male Wistar rats $(n=72)$ weighing $200-225 \mathrm{~g}$ were housed in groups of five in animal quarters with a 12 hour day/night cycle. Standard pelleted rat food (Paterson and the Christopher Hill Group, Porton-diet PRD) and water were freely available. After 48 hours' acclimatisation, animals were randomised to receive either $90 \%$ proximal small bowel resection (as measured from the ligament of Treitz) or jejunal transection and resuture (controls). Operations were carried out under light ether anaesthesia. A continuous $6 / 0$ silk suture was used for intestinal anastomoses.

Immediately after the operation, half the animals in each group were further randomised to receive either CR-1409 (12 mg/kg/day) or saline $(3 \mathrm{ml} / \mathrm{kg}$ ) by daily subcutaneous injection. CR-1409 was dissolved in distilled water and brought to $\mathrm{pH} 9$ by $0.01 \mathrm{~N} \mathrm{NaOH}$ to give a $0.4 \%$ solution. Food was reintroduced 12 hours postoperatively. After overnight fastirı, representatives of each of the four groups were killed at 1,2 , 
and 3 weeks after operation. Blood was obtained by direct cardiac puncture for cholecystokinin assay. The pancreas was excised, trimmed free of adherent fat and lymph nodes, and weighed. Small samples were removed for protein and nucleic acid content measurement, BrdUrd labelling index, and PCNA immunoreactive cell count.

\section{NUCLEIC ACID AND PROTEIN CONTENTS}

Pancreatic tissue was homogenised in phosphate buffered saline (PBS) $(136.9 \mathrm{mmol} / 1 \mathrm{NaCl}, 2 \cdot 7$ $\mathrm{mmol} / \mathrm{l} \mathrm{KCl}, 8.1 \mathrm{mmol} / 1 \mathrm{Na}_{2} \mathrm{HPO}_{4}, 1.5 \mathrm{mmol} / \mathrm{l}$ $\mathrm{KH}_{2} \mathrm{PO}_{4}, 0.9 \mathrm{mmol} / 1 \mathrm{CaCl}_{2}, 0.5 \mathrm{mmol} / \mathrm{l} \mathrm{MgCl}_{2}-$ $6 \mathrm{H} 2 \mathrm{O}$, adjusted to $\mathrm{pH} 7 \cdot 5$ with $\mathrm{NaOH}$ ), and the concentration of the homogenate was adjusted to $1 \mathrm{mg}$ tissue per ml. Pancreatic contents of DNA and RNA were assayed by the fluorimetric method of Boer ${ }^{12}$ but using an excitation wavelength of $536 \mathrm{~nm}$ and an emission wavelength of $602 \mathrm{~nm} .{ }^{13}$ Protein content was determined by the method of Lowry et al. ${ }^{14}$ Since body weight has a profound effect on pancreatic weight, ${ }^{15}$ the results were expressed as mg per $100 \mathrm{~g}$ body weight to correct for this variable.

\section{BRDURD LABELLING INDEX}

BrdUrd is a thymidine analogue that is readily and specifically incorporated into DNA during the $S$ phase of the cell cycle. Rats were given an intraperitoneal injection of BrdUrd $(50 \mathrm{mg} / \mathrm{kg}$ body weight) one hour before sacrifice. A small sample of the excised pancreas was placed in Carnoy's solution (absolute alcohol:chloroform: glacial acetic acid=6:3:1 by volume) for two to four hours and transferred to $75 \%$ ethanol. Tissue was processed in chloroform, wax embedded, and $4 \mu \mathrm{m}$ sections were cut. Sections were dewaxed and dehydrated in $100 \%$ alcohol. Endogenous peroxidase activity was removed by subsequent immersion in methanol/hydrogen peroxide $(98 \cdot 4 \% / 1 \cdot 6 \%)$. Dissociation of histones was achieved by using $1 \mathrm{~mol} / \mathrm{l} \mathrm{HCl}$, which also partially denatured DNA. Each section was treated with a drop of primary antibody (mouse anti-human BrdUrd, Dako, High Wycombe; $1: 20$ dilution in PBS). After overnight incubation at $4^{\circ} \mathrm{C}$, the section was incubated with a peroxidase conjugated second antibody (rabbit anti-mouse IgG, 1:50 dilution with PBS) for one hour at room temperature. The colour reagent diaminobenzidine plus $\mathrm{H}_{2} \mathrm{O}_{2}$ was used for staining, and each section was counterstained with haematoxylin. The number of labelled cells in each section was estimated from a count of 2000 exocrine pancreatic acinar cells, and the result was expressed as a percentage - the labelling index.

\section{PCNA LABELLING INDEX}

PCNA is an acidic nuclear protein, expression of which is directly correlated with rates of cell proliferation and DNA synthesis. The monoclonal antibody PC10 will 'recognise' PCNA in conventionally fixed and processed histological material. The tissue sample of the excised pancreas was placed in buffered formalin for two to four hours and transferred to $75 \%$ ethanol.
Tissue was processed in chloroform and embedded in wax before $4 \mu \mathrm{m}$ sections were cut. Sections were dewaxed and taken down through graded alcohols; endogenous peroxidase activity was blocked by incubating the sections in $3 \%$ hydrogen peroxide and methanol for one hour.

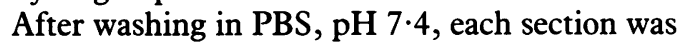
treated with a drop of primary antibody (1:20 dilution in PBS). After overnight incubation at $4^{\circ} \mathrm{C}$, the sections were washed in PBS, $0 \cdot 1 \%$ bovine serum albumin (BSA), and Tris-BSA. The second layer antibody, biotinylated goat anti-mouse IgG (Vector Laboratories, Burlingame, CA, USA) was applied at a dilution of 1:50 and incubated for two hours at room temperature. After washing in PBS, streptavidin-peroxidase (Jackson Immunonuclear Laboratories, Westgrove, PA, USA) was applied to the sections at a 1:5000 dilution in PBS with $1 \%$ BSA for 30 minutes at room temperature. Diamino-benzidine-hydrogen peroxide was employed as a chromogen, and a light haematoxylin counterstain was used. The PCNA labelling index was estimated from a count of 2000 exocrine acinar cells and expressed as a percentage.

\section{PLASMA CCK ASSAY}

Plasma CCK peptides were extracted from cardiac blood samples with C18 'SepPak' cartridges (Water, Harrow, UK), ${ }^{16}$ and eluates were dried by centrifugal evaporation (Savant, Famingdale, NY, USA). CCK was measured by a specific radioimmunoassay based on antiserum $A_{2}$, raised by immunising a rabbit with natural porcine CCK-33 (donated by Professors V Mutt and $S$ R Bloom). Antiserum $A_{2}$ (1:60000) was incubated at $4^{\circ} \mathrm{C}$ for three days with standard CCK-8 or with plasma samples plus CCK-8 tracer labelled with iodine-125 (1000 cpm, Amersham, UK) in 0.05 mol $/ 1$ sodium phosphate buffer $(\mathrm{pH} 7.4)$ with $0.25 \%$ gelatin and $0.01 \%$ $\mathrm{mol} / \mathrm{l}$ ethylenediamine tetra-acetic acid (EDTA). Free and bound tracer were separated by the addition of $6 \%$ (weight/volume) charcoal (Norit PN5, BDH, Poole, UK) with $0.6 \%$ (weight/ volume) dextran. The concentrations of pure

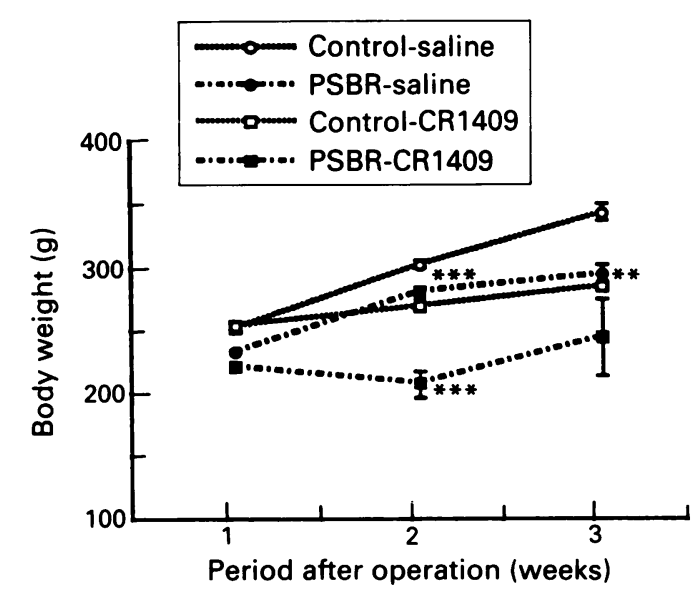

Figure 1: Body weight in rats with proximal small bowel resection (PSBR) or transection (control). (Values, mean $(S E M)$.) Significance v corresponding control: ${ }^{\star} p<0 \cdot 002$ $\star \star \star p<0.001$. 

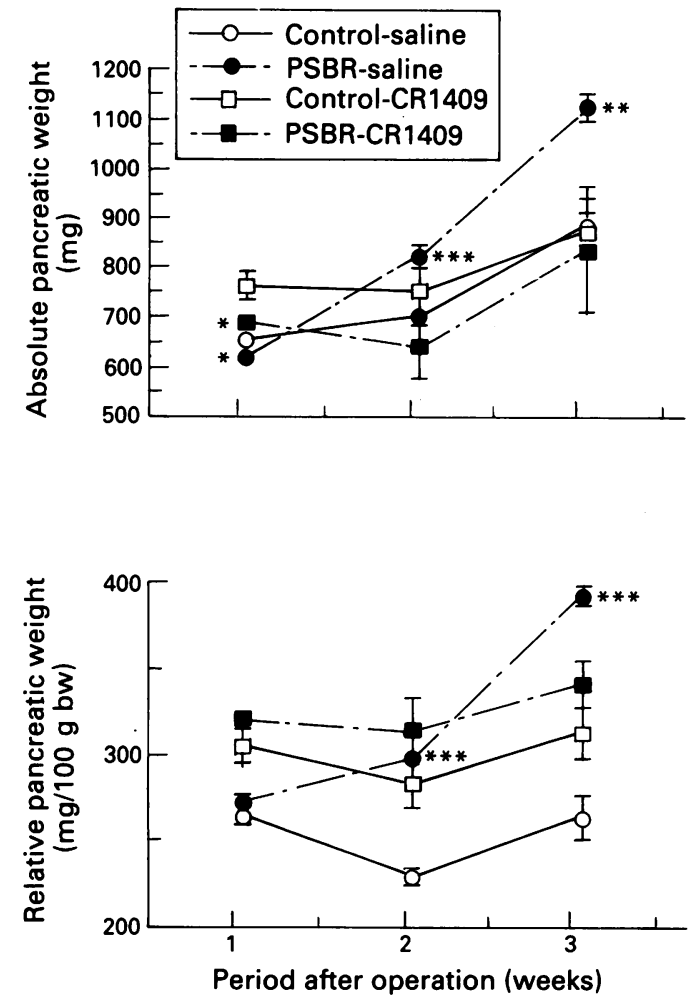

Figure 2: Pancreatic weight (absolute and relative) in rats with proximal small bowel resection $(P S B R)$ or transection (control). (Values, mean (SEM).) Significance v corresponding control: ${ }^{\star} p<0.05,{ }^{\star \star} p<0.002,{ }^{\star \star \star} p<0.005$.

peptides that produced half maximal inhibition of binding of tracer to $A_{2}$ were $2.0 \mathrm{pmol} / 1$ for CCK-8, $2 \cdot 4 \mathrm{pmol} / \mathrm{l}$ for CCK-33, and $2 \cdot 2 \mathrm{nmol} / \mathrm{l}$ for gastrin 17 . The coefficient of variation within assays was $8 \cdot 2 \%$ and between assays $12 \cdot 8 \%$. The sensitivity of the assay (defined as minimal amount of CCK-8 that could be distinguished from zero with $95 \%$ confidence) was $0.2 \mathrm{pmol}$, and the recovery of CCK-8 and CCK-33 through the SepPak and assay procedure was $79 \%$.

\section{ULTRASTRUCTURAL STUDIES}

Samples of all categories of pancreas, not exceeding $1 \mathrm{~mm}^{3}$ in volume, were fixed in $2 \%$ glutaraldehyde for two hours. After washing in phosphate buffer, tissues were osmicated and dehydrated in acidified DMP before routine embedding in Taab resin. Sections $(1 \mu \mathrm{m})$ were cut and stained with toluidine blue for observation by light microscopy, followed by ultrathin sections of approximately $100 \mathrm{~nm}$, collected on nickel grids and stained with uranyl acetate and lead citrate, for observation on a Philips CM-10 electron microscope.

\section{STATISTICAL ANALYSIS}

Student's $t$ test for unpaired data was used for the group analysis. Nucleic acid and protein contents and plasma CCK values were expressed as mean (SEM), whereas those of BrdUrd labelling index and PCNA labelling index were expressed as medians. The Spearman correlation coefficient was used to assess the correlation between the results of the BrdUrd and PCNA labelling indices.

\section{Results}

MORTALITY AND BODY WEIGHT (Fig 1)

There were two deaths from anastomotic leakage (one control and one PSBR rat). Rats undergoing massive small bowel resection weighed less than controls both at one and two weeks whether or not they received CR-1409 (8-14\% less at one week, $\mathrm{p}<0.001 ; 10-24 \%$ less at two weeks, $\mathrm{p}<0.001)$. By three weeks, resection rats weighed $15 \%$ less than controls, but there was no difference in body weight between the resection and transection animals receiving CR-1409.

PANCREATIC WEIGHT (Fig 2)

Proximal small bowel resection had a clearcut effect on both absolute and relative pancreatic weight. Absolute pancreatic weight was 4.9$9 \%$ less than controls at one week but was $18 \%$ greater than controls at two weeks and $27 \%$ greater at three weeks. Likewise, enterectomy caused a $32 \%$ increase in relative pancreatic weight over controls at two weeks and a $50 \%$ increase at three weeks. CR-1409 completely abolished this pancreatic growth, so that differences in absolute and relative pancreatic weights between resection and transection animals were no longer significant.
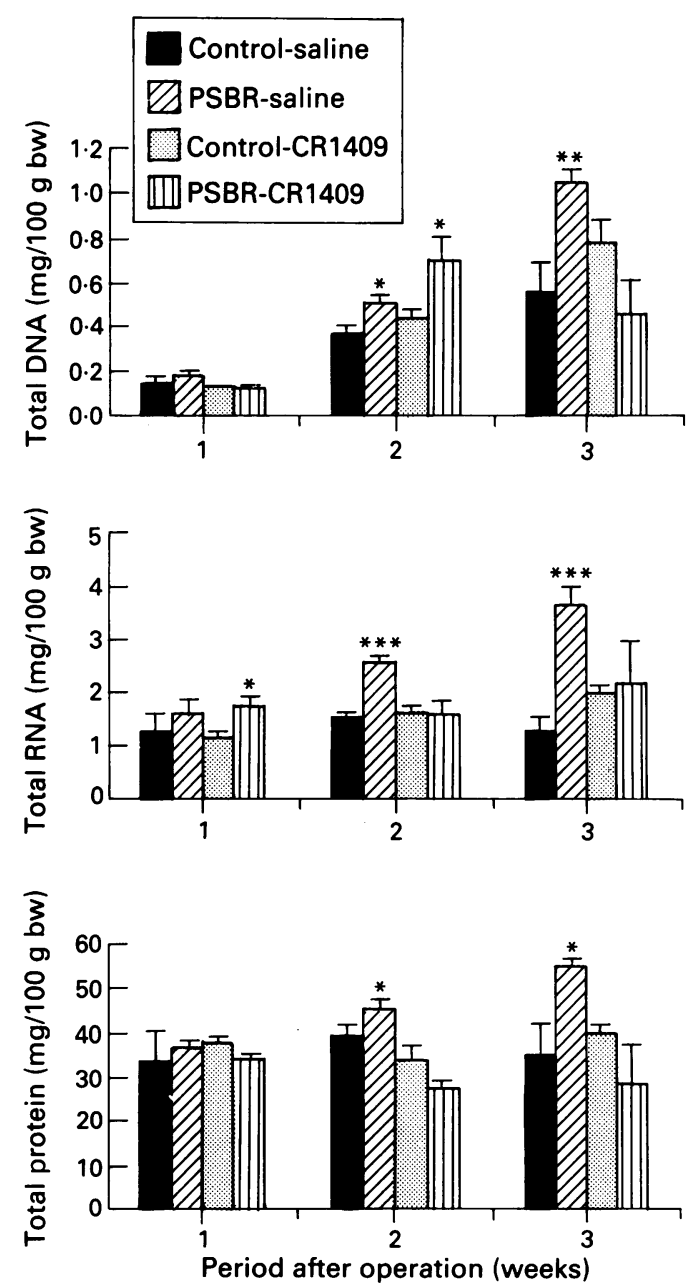

Figure 3: Pancreatic nucleic acid and protein contents per $100 \mathrm{~g}$ body weight in rats with proximal small bowel resection (PSBR) or transection (control). (Values, mean (SEM).) SSBR) or transection (control). (Values, mean (SEM).)
Significance v corresponding control: ${ }^{\star} p<0.05,{ }^{\star} p<0.002$, $\star \star \star p<0.001$ 
Plasma cholecystokinin concentrations ( $p$ molll) in rats with proximal small bowel resection $(P S B R)$ or transection (control).

\begin{tabular}{|c|c|c|c|c|}
\hline \multirow{2}{*}{$\begin{array}{l}\text { Period post } \\
\text { operation } \\
\text { (wks) }\end{array}$} & \multicolumn{4}{|l|}{ Group } \\
\hline & $\begin{array}{l}\text { Control- } \\
\text { saline }\end{array}$ & $\begin{array}{l}\text { PSBR - } \\
\text { saline }\end{array}$ & $\begin{array}{l}\text { Control- } \\
C R-1409\end{array}$ & $\begin{array}{l}P S B R- \\
C R-1409\end{array}$ \\
\hline $\begin{array}{l}1 \\
2 \\
3\end{array}$ & $\begin{array}{l}2.69(0.29) \\
2.93(0.48) \\
2.77(0.30)\end{array}$ & $\begin{array}{l}4.92(0.66)^{\star} \\
5.91(1.13)^{\star} \\
5.43(0.78)^{\star}\end{array}$ & $\begin{array}{l}2.90(0.35) \\
3.74(0.66) \\
2.76(0.47)\end{array}$ & $\begin{array}{l}5.52(0.54)^{\star \star} \\
7.43(1.03)^{\star} \\
7.45(1.99)^{\star}\end{array}$ \\
\hline
\end{tabular}

Significance $v$ corresponding control. ${ }^{\star} \mathrm{p}<0 \cdot 05,{ }^{\star \star} \mathrm{p}<0.005$. Values mean $(\mathrm{SEM})$.

\section{PLASMA CHOLECYSTOKININ (Table)}

Small bowel resection caused a sustained increase in circulating CCK concentrations - by $83 \%$ at one week, by $102 \%$ at two weeks, and by $96 \%$ at three weeks. Administration of CR-1409 had no appreciable effect on plasma hormone concentrations.

NUCLEIC ACID AND PROTEIN CONTENTS (Fig 3)

Pancreatic nucleic acid and protein contents increased after proximal small bowel resection, but the increase did not attain statistical significance until two weeks, when DNA was $34 \%$ higher, RNA $60 \%$ higher, and protein $20 \%$ higher than in controls. These changes were more obvious by three weeks, when increments were $82 \%, 178 \%$, and $57 \%$. With the exception of the DNA contents at two weeks, the CCK antagonist completely inhibited growth stimulation produced by PSBR.

BRDURD LABELLING INDEX (Fig 4)

One week after PSBR, the labelling index was already higher than in controls $(0.35 v 0.05 \%)$. The increase in proliferative response became increasingly obvious at two weeks $(1.43 v 0.20 \%)$ and was still present at three weeks $(0.88 v$ $0 \cdot 35 \%)$. CR-1409 abolished the effect of proximal enterectomy, so that there was no difference from control values at any time point. The antagonist had no effect in rats with small bowel transection.

PCNA LABELLING INDEX (Fig 5)

Broadly similar results were obtained for the

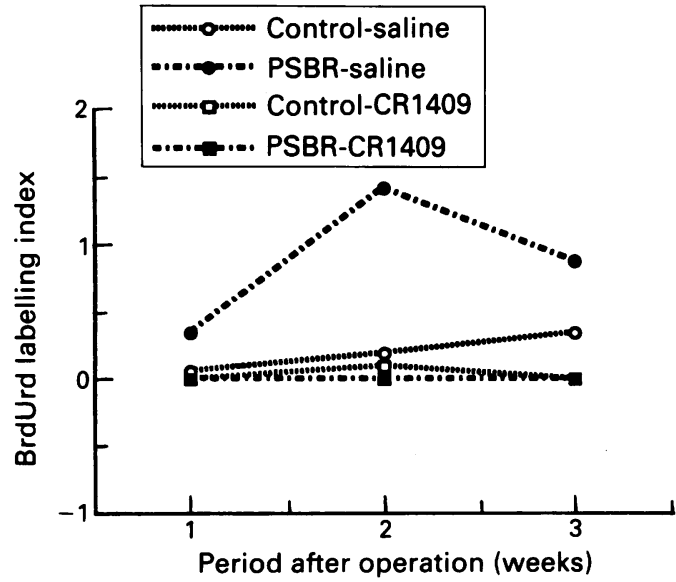

Figure 4: Bromodeoxyuridine (BrdUrd) labelling index of the pancreas in rats with proximal small bowel resection (PSBR) or transection (control). (Values, median.)

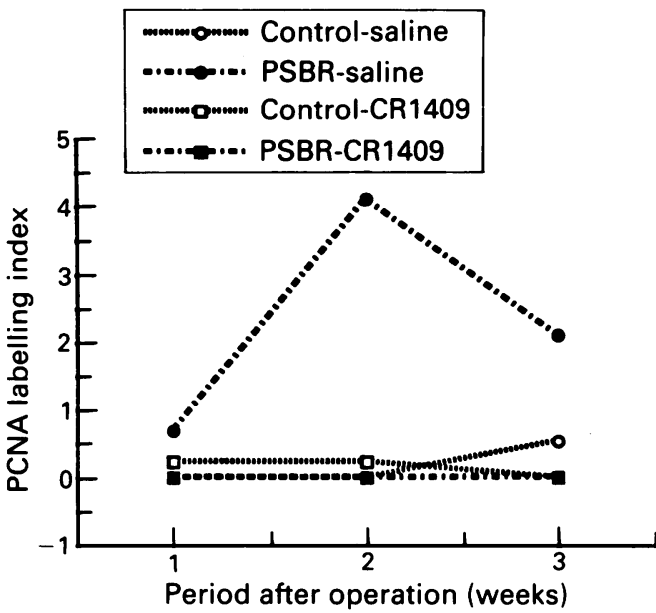

Figure 5: Proliferating cell nuclear antigen (PCNA) labelling index of the pancreas in rats with proximal small bowel resection (PSBR) or transection (control). (Values, median.)

cell kinetic data derived by counting PCNA immunoreactive cells. PSBR caused an increase in the proliferation rate at one week $(0.70 v 0 \%)$. The differences were more marked both at two weeks $(4 \cdot 13 v 0 \%)$ and at three weeks $(2 \cdot 10 v$ 0.55). Again, CR-1409 largely abolished the growth stimulation produced by bowel resection but had no consistent effect within the control groups. There was a correlation between the BrdUrd labelling index and the PCNA labelling index, with a Spearman correlation coefficient of 0.68 .

\section{ULTRASTRUCTURAL STUDIES}

Samples of pancreas from rats with transection and saline injection showed no differences from normal pancreas. Acinar cells were typically pyramidal in shape with closely packed rough endoplasmic reticulum, numerous mitochondria and abundant apical zymogen granules (Fig 6). By contrast, samples from animals with PSBR and saline showed incipient vacuole formation in the rough endoplasmic reticulum of many acinar cells, associated with marked degranulation (Fig 7). No degranulation was noted in either transection or resection animals that had been treated with CR-1409, but incipient vacuolation of the rough endoplasmic reticulum was a feature of all CR-1409 treated tissues as well as those of the PSBR group (Fig 8).

\section{Discussion}

In line with other work, ${ }^{7817}$ the present data show that an extensive proximal small bowel resection stimulates pancreatic growth, as characterised by increased wet weight and increased DNA, RNA, and protein contents. The pattern of this adaptive growth is mainly one of hyperplasia, since the RNA/DNA ratio was little changed. Increased organ mass was accompanied by increases in two markers of cell proliferation, the BrdUrd and PCNA labelling indices.

Our results firmly implicate CCK as a key intermediary in the adaptive response of the pancreas to massive proximal small bowel resection. Not only were CCK levels increased two to 


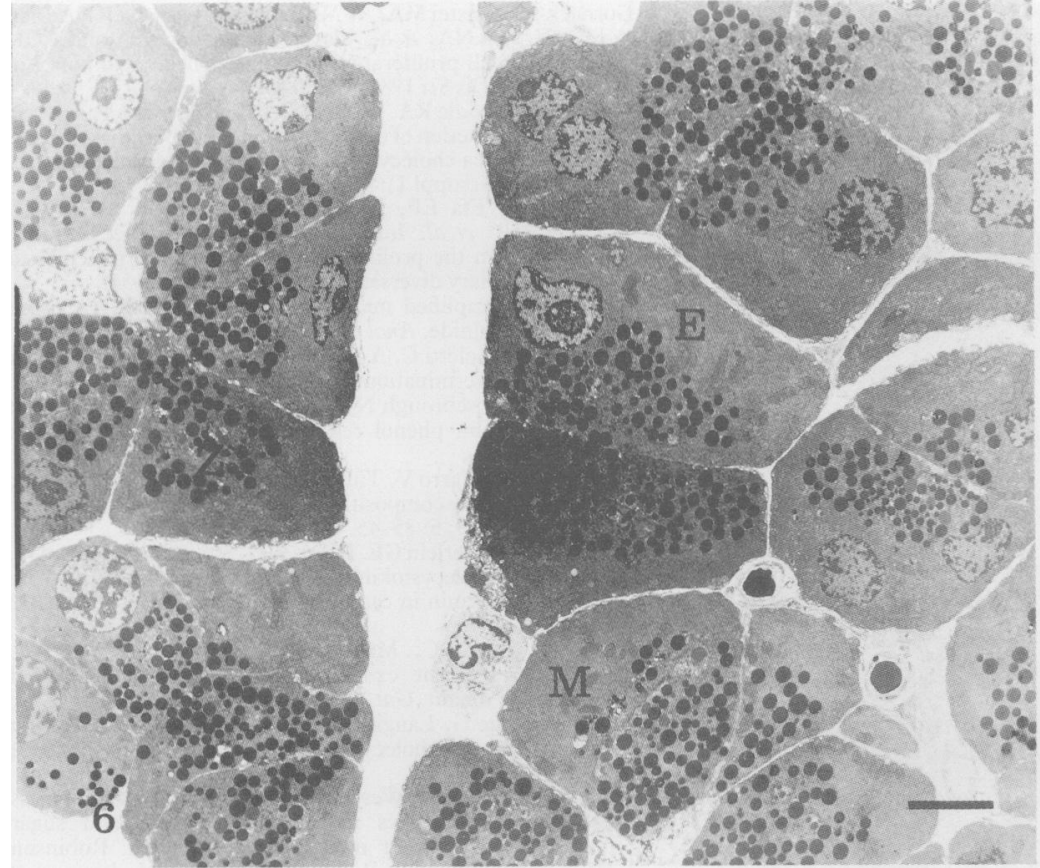

Figure 6: Normal ultrastructure of pancreatic acinar cells (original magnification $\times 2400$, bar $=6 \cdot 3 \mu \mathrm{m}) . E=$ rough endoplasmic reticulum; $M=$ mitochondria $Z=z y m o g e n$ granules.

threefold at the relevant time (one to three weeks postoperatively), but the specific antagonist CR-1409 completely abolished the increase in pancreatic mass and cell proliferation. Since CR1409 did not interfere with circulating concentrations of the hormone, it seemed to work by receptor blockade. Hypercholecystokininaemia after enterectomy was reported by Lilja $e t$ al in $1983^{6}$ and confirmed at our institute the following year. ${ }^{9}$ Unlike gastrin, the increased CCK is not a transitory response but continues for at least 15 weeks. ${ }^{6}$ There are at least three possible

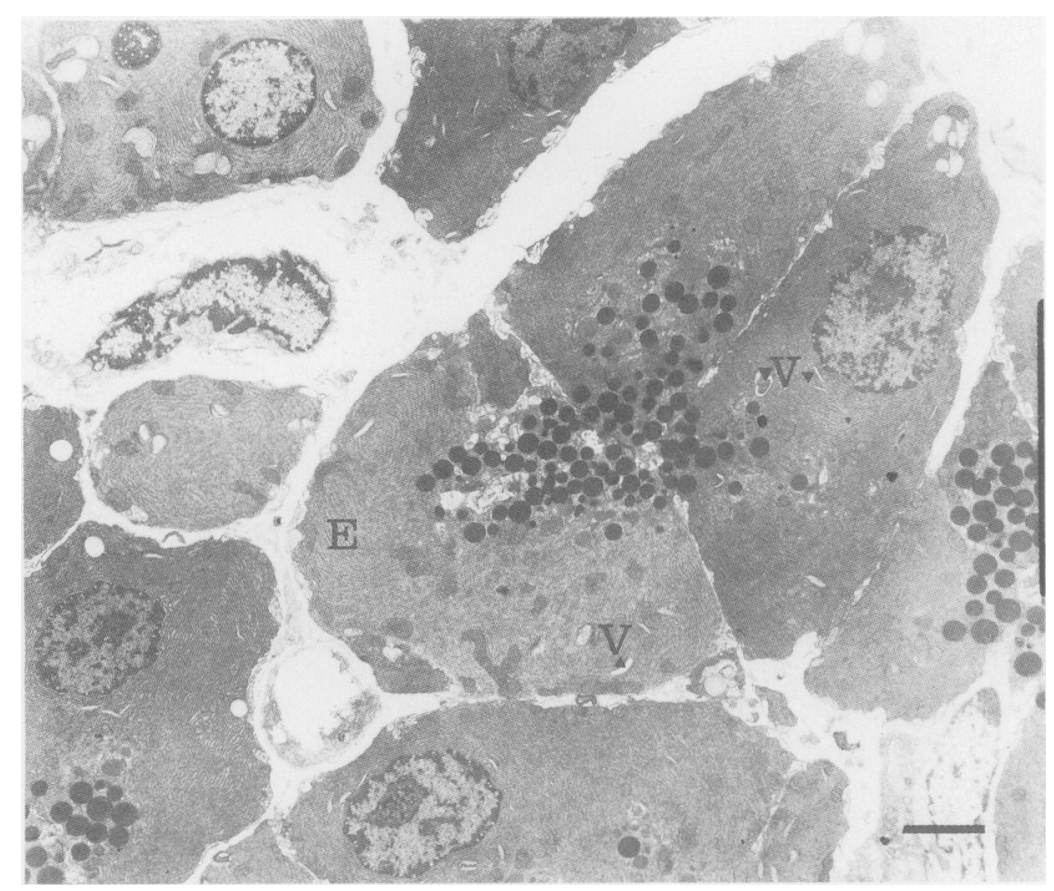

Figure 7: Ultrastructural changes in pancreatic acinar cells following proximal small bowel resection plus saline administration (original magnification $\times 4400$, bar $=3 \cdot 4 \mu \mathrm{m}$ ). Note the scarcity of zymogen granules. $E=$ rough endoplasmic reticulum; $V=$ incipient vacuolation of rough endoplasmic reticulum. explanations: (1) loss of a negative feedback mechanism on CCK release by a depletion of the anticholecystokinin peptide normally released from the ileum ${ }^{18}$ since our procedure removed more than $80 \%$ of the ileum; (2) hyperplasia of the endocrine cells within the remaining intestine, notably those in the duodenum (modest duodenal hyperplasia follows jejunectomy ${ }^{19}$; and (3) impaired elimination of CCK after removal of jejunoileum.

Immunohistological methods of assessing cell proliferation have particular advantages over other techniques because of the maintenance of cellular and tissue architecture, the relative simplicity of the methodology, and the rapidity of results. Pancreatic acinar cell kinetics can be estimated by using the methods of BrdUrd labelling index and metaphase arrest after vincristine administration." Recently, PCNA, an auxiliary protein of DNA polymerase-delta, has been shown to play a critical role in the initiation of cell proliferation. ${ }^{20}$ The distribution of PCNA in the cell cycle makes it a useful marker for proliferating cells: increasing through $G_{1}$, peaking at the $G_{1} / S$ phase interface, decreasing through $G_{2}$, and reaching low levels (which are virtually undetectable by immunocytochemical methods) in $M$ phase and quiescent $\left(\mathrm{G}_{0}\right)$ cells. ${ }^{21-23}$ PCNA can be demonstrated by using monoclonal antibodies, usually requiring cryostat sections or specially prepared histological material. PC10 is a new antibody that has the advantage of recognising PCNA in conventionally fixed and processed histological material..$^{2+}$ As expected, there were more PCNA staining cells than BrdUrd-incorporating cells giving the PCNA technique a potential advantage in organs like the pancreas where there is low level of proliferative activity.

Our preliminary studies indicate that raised circulating levels of CCK cause degranulation in pancreatic acinar cells. ${ }^{25}$ Animals that underwent proximal enterectomy alone demonstrated acinar cell degranulation typical of the response to raised CCK levels, but these changes were not seen after treatment with the antagonist. Thus, CR-1409 not only abrogates the tropic effect of CCK on pancreatic growth but also inhibits functional stimulation of the exocrine cell. The distension of the rough endoplasmic reticulum and the cell vacuolation caused by the antagonist probably reflect a direct effect on pancreatic acinar cells.

We thank the Royal Postgraduate Medical School and the Hammersmith and Queen Charlotte's Special Health Authority for supporting this research and Dr W K Man and Mr S K Li for the nucleic acid and protein assay. The CCK antagonist CR-1 409 the nucleic acid and protein assay. The CCK antagonist CR-1409 was kindly provided by Dr L Rovati of Rotta Research Laboratories (Milan, Italy), and the PC10 antibody was donated
by Professor David Lane, CRC Cell Transformation Research Group, Department of Biochemistry, University of Dundee.

1 Bristol JB, Williamson RCN. Nutrition, operations, and Bistol JB, Williamson RCN. Nutrition, operations, and
intestinal adaptation. F Parenter Enteral Nutr 1988; 12:299 309

2 Watanapa P, Beardshall K, Calam J, Williamson RCN. The tropic role of enteroglucagon in pancreatic adaptation $t$ subtotal enterectomy. Br F Surg 1991; 78: 917-20.

3 Stewart ID, Flaks B, Watanapa P, Davies PW, W'illiamson RCN. Pancreatobiliary diversion enhances experimental pancreatic carcinogenesis. Br F Cancer 1991; 63: 63-6.

+ Gelinas MD, Morin CI, Morisset J. Exocrine pancreatic function following proximal small bowel resection in rats. F Phvsiol 1982; 322: 71-82

5 Sagor GR, Al-Mukhtar MY'T, Ghatei MA, Wright NA, Bloom $S R$. The effect of altered luminal nutrition on cellular 


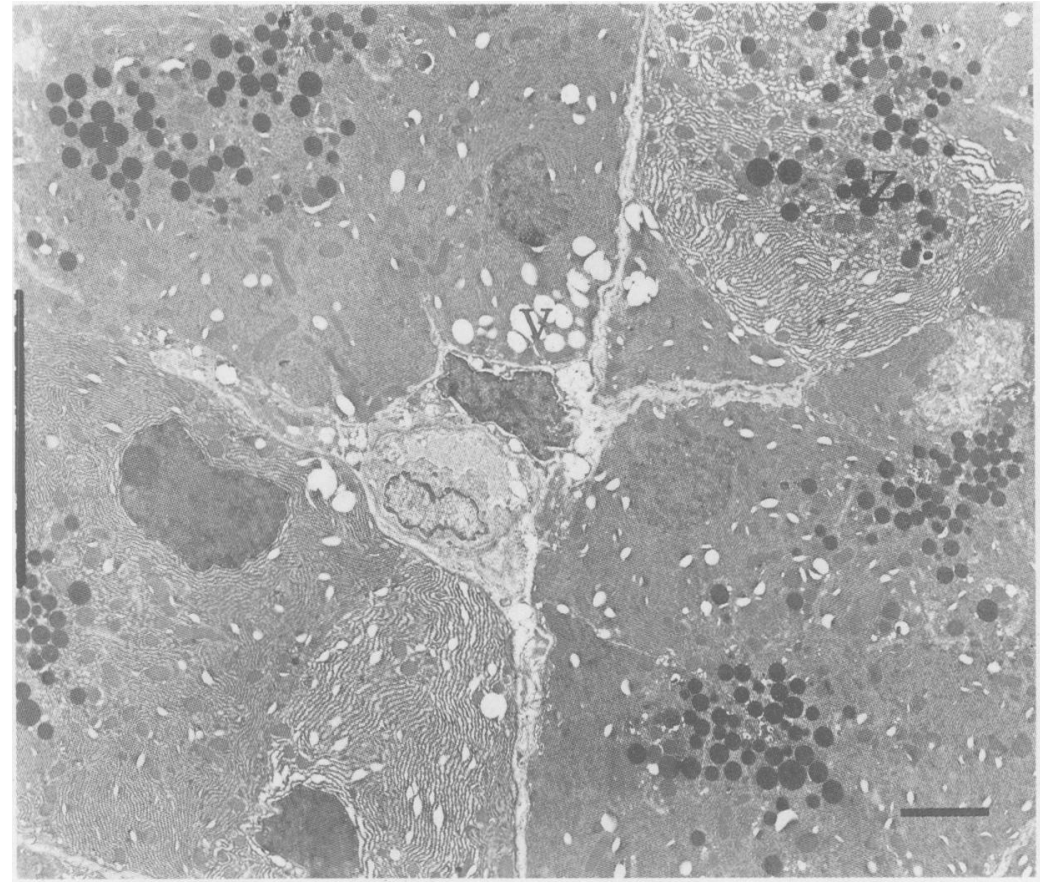

Figure 8: Ultrastructural changes in pancreatic acinar cells after proximal small bowel resection plus CR-1409 administration (original magnification $\times 4400$, bar $=3 \cdot 4 \mu \mathrm{m}$ ). $V=$ incipient valuolation of rough endoplasmic reticulum; $Z=$ zymogen granules.

proliferation and plasma concentrations of enteroglucagon and gastrin after small bowel resection in the rat. $\mathrm{Br} \mathcal{F}$ Surg 1982; 69: 14-8

6 Lilja P, Wiener I, Inoue $\mathrm{K}$, Thompson JC. Changes in circulating levels of cholecystokinin, gastrin and pancreatic polypeptide after small bowel resection in dogs. Am $\mathcal{F}$ Surg 1983; 145: 157-63.

7 Stock-Damge C, Aprahamian M, Lhoste E, Pousse A, Humbert W, Noriega $\mathrm{R}$, et al. Pancreatic hyperplasia after small bowel resection in the rat: dissociation from endogeneous gastrin levels. Digestion 1984; 29: 223-30.

8 Stock-Damge C, Lhoste E, Aprahamian M, Pousse A. Gastrin modulation of pancreatic growth. Scand $\mathcal{7}$ Gastroenterol $1985 ; 20$ (suppl 112): 68-74.
9 Gornacz GE, Ghatei MA, Al-Mukhtar MYT, Yeats JC, Adrian TE, Wright NA, et al. Plasma enteroglucagon and CCK levels and cell proliferation in defunctioned small bowel in the rat. Dig Dis Sci 1984; 29: 1041-9.

10 Niederau C, Liddle RA Williams JA, Grendell JH Pancreatic growth: interaction of exogenous cholecystokinin, a protease inhibitor and a cholecystokinin receptor antagonist in mice. Gut 1987; 28 (suppl 1): 63-9.

11 Watanapa P, Efa EF, Beardshall K, Calam J, Sarraf CE, Alison MR, et al. Inhibitory effect of a cholecystokinin antagonist on the proliferative response of the pancreas to pancreatobiliary diversion. Gut 1991; 32: 1049-54.

12 Boer GJ. A simplified microassay of DNA and RNA using ethidium bromide. Anal Biochem 1975; 65: 225-31.

13 Le Pecq JB, Paoletti C. A new fluorometric method for RNA and DNA determination. Anal Biochem 1966; 17: 100-7.

14 Lowry OH, Rosebrough NJ, Farr AL. Protein measuremen with the Folin phenol reagent. F Biol Chem 1951; 127: $182-6$.

15 Nagy I, Pap A, Varro V. Time-course of changes in pancreatic size and enzyme composition in rats during starvation. Int $\mathcal{F}$ size and enzyme composition $1989 ; 5$ : $35-45$.

16 Eysellein VE, Eberlein GE, Hesse WH, Suger MV, Goebell H, Reeve JR. Cholecystokinin-58 is the major circulating form of cholecystokinin in canine blood. 7 Biol Chem 1987; 262: 214-7.

17 Haegel P, Stock C, Marescaux J, Petit B, Grenier JF Hyperplasia of the exocrine pancreas after small bowe resection in the rat. Gut 1981; 22: 207-12.

18 Sarles H, Hage G, Laugier R, Demol P, Bataille D. Presen status of the anticholecystokinin hormone. Digestion 1979; 19: 73-6.

19 Urban E, Michel AM, Weser E. Dissociation of mucosal mass and adaptive changes in electrolyte, water and sugar transport in rats after intestinal resection. In: Robinson transport in rats after intestinal resection. In: Robinson
JWL, Dowling RH, Riecken E-O, eds. Mechanisms of intestinal adaptation. Lancaster: MTP Press Ltd, 1982: intestinal

20 Jaskulski D, DeRiel JK, Mercer WE, Calabretta B, Baserga R. Inhibition of cellular proliferation by antisense oligodeoxynucleotides to PCNA/cyclin. Science 1988; 240: 1544-6.

21 Kurki P, Ogata K, Tan EM. Monoclonal antibodies to proliferating cell nuclear antigen (PCNA)/cyclin as probes for proliferating cells by immunofluorescence microscopy
and flow cytometry. F Immunol Methods 1988; 109: 49-59.

22 Kurki P, Vanderlaan M, Dolbeare F, Gray J, Tan EM. Expression of proliferating cell nuclear antigen (PCNA)/ cyclin during the cell cycle. Exp Cell Res 1986; 166: 209-19.

23 Morris GF, Mathews MB. Regulation of proliferating cell nuclear antigen during the cell cycle. 7 Biol Chem 1989; 264: nuclear an

24 Hall PA, Levison DA, Woods AL, Yu CC-W, Kellock DB Watkins JA, et al. Proliferating cell nuclear antigen (PCNA) immunolocalization in paraffin sections: an index of cell proliferation with evidence of deregulated expression in some neoplasms. F Pathol 1990; 162: 285-94.

25 Sarraf CE, Watanapa P, Efa E, Alison MR. Pancreatic hyperplasia as a result of pancreatobiliary diversion (PBD) f Pathol 1990; 161: 351A. 